IIIIIIIIIIIIIIIIIIIIIIIIIIIIIIIIIIII

Original Article

IIIIIIIIIIIIIIIIIIIIIIIIIIIIIIIIIII

\title{
Dissipation kinetics of glyphosate in tea and tea-field under northwestern mid-hill conditions of India
}

\author{
Bandana Bandana, ${ }^{1}$ Neelam Sharma, ${ }^{2}$ Robin Joshi, ${ }^{3}$ Ashu Gulati ${ }^{3}$ and Shobha Sondhia ${ }^{4, *}$ \\ ${ }^{1}$ Central Potato Research Institute Campus, Modipuram 250110, India \\ ${ }^{2}$ CSKHPKV Palampur (HP), Agronomy division 176062, India \\ ${ }^{3}$ CSIR-IHBT Palampur (HP), HATS division 176061, India \\ ${ }^{4}$ Directorate of Weed Science Research, Jabalpur 482004, India
}

(Received September 22, 2014; Accepted March 10, 2015)

\begin{abstract}
A study was conducted to determine the dissipation of glyphosate applied at three dose levels in tea crop in mid hill conditions of northwest Himalaya, India in two consecutive seasons. More than $65 \%$ of the initial residues in the soil were found to have dissipated within 30 days following application to the tea irrespective of the dose. Glyphosate persisted in the soil for up to 30, 45 and 60 days at application doses of $0.5,1.0$ and $2.0 \mathrm{~kg} / \mathrm{ha}$, respectively. Glyphosate residues in the tea leaves were detected for up to 15 days with all three treatments. Half lives of glyphosate ranged from 5.80 to 19.10 days in the soil of the tea fields and 5.82 to 7.91 days in the tea leaves at the three doses. Glyphosate concentrations in the tea leaves were found to be below the maximum residue limit $(1 \mathrm{mg} / \mathrm{kg})$. (C) Pesticide Science Society of Japan
\end{abstract}

Keywords: glyphosate, soil, tea leaves, residues, dissipation, rate kinetics.

\section{Introduction}

Tea is the most popular nonalcoholic beverage in the world; it has been consumed for thousands of years for its alluring flavors and health benefits. Numerous epidemiological and preclinical studies have demonstrated that drinking tea may reduce the risk of cancer and cardiovascular diseases. ${ }^{1,2)}$ India has the unique distinction of being the second-largest producer and consumer of tea in the world. The Indian tea industry produces more than 1000 million $\mathrm{kg}$ of tea from an area of 579.35 thousand hectares. ${ }^{3)}$ The tea industry in India has an annual turnover of 8 million USD and provides employment to a million people. The state of Himachal Pradesh representing the mid-hills of northwestern Himalaya, contributes $0.01 \%$ of the country's tea production. An increase in the production of tea in India is mainly attributed to efficient and integrated agricultural practices including efficient weed management practices.

Weeds compete with crops for nutrients, sunshine and moisture. Besides reducing the yield, weeds also have adverse effects on the growth of tea viz. restricted branching, frame development in younger tea shoots, reduced plucking efficiency, and harboring and serving as alternate hosts for many organisms including some important pests of tea. Depending upon the inten-

\footnotetext{
* To whom correspondence should be addressed.

E-mail: shobhasondia@yahoo.com

Published online June 24, 2015

(C) Pesticide Science Society of Japan
}

sity of weed growth, the extent of competition and the weed species, weeds reduce the productivity of tea by $10-50 \% .{ }^{4-6)}$ Thus, all of these situations make it necessary to rely on herbicides for effective and timely weed control. In tea plantations, the use of herbicides as a tool for controlling weeds is very popular and has been widely used ever since the introduction of herbicides-primarily due to their cost-effectiveness, their efficiency in controlling diverse weed flora and their requirement for less labor. Lately, the use of herbicides in India is on the rise on tea plantations and their increased use may pose opportunities for chemicals to drift to non-target areas; therefore it is imperative to work out the risk of environmental contamination including the quality of farm produce after field application of the chemicals. Although the herbicide application is target specific, there is always potential for the drifting of chemicals onto non-target plants also. ${ }^{7)}$

Glyphosate, $N$-(phosphonomethyl)glycine is a widely used herbicide worldwide in the world in non-cropped and cropped situations including tea plantations, vineyards and roadside. ${ }^{7,8)}$ It is a systemic herbicide that is absorbed by foliage and then translocated throughout the plant via phloem.

Data on the rate of degradation are extremely important as they permit prediction of the levels likely to remain in the soil and allow assessment of the risk associated with exposure, ${ }^{8-12)}$ and contamination of tea leaves. On degradation, glyphosate yields, AMPA (amino methyl phosphonic acid) a major metabolite of glyphosate which finally degrades and mineralizes to $\mathrm{CO}_{2}$. Degradation of glyphosate occurs under aerobic and anaerobic 
conditions in soils and sediments. ${ }^{13-16)}$

Although much information on the fate of glyphosate in the soil is available, little information regarding glyphosate in tropical soil is available. Indiscriminate use of glyphosate on tea lands in some Asian countries has adversely affected the health and productivity of tea bushes in recent years. ${ }^{17)}$ Furthermore, increasing levels of glyphosate residues have been reported in some Sri Lankan tea exported to other countries. Therefore, the present study was undertaken to study the dissipation and fate of glyphosate residues in tea leaves and soil.

\section{Materials and Methods}

\section{Design of the field experiment}

The field experiment was conducted in plots set up in a tea plantation area (Tea variety Kangra Jawala) of the Research Farm of the Department of Tea Husbandry and Technology, CSKHPKV Palampur, India located at $32^{\circ} 6^{\prime} \mathrm{N}$ latitude, $76^{\circ} 3^{\prime} \mathrm{E}$ longitude and at an altitude of about $1290 \mathrm{~m}$ above mean sea level. The experimental site falls in the subtemparate and mid-hill zone of Himachal Pradesh, India. The experiment was laid out in a completely randomized block design with five replications. Field trials were conducted in 2008 and 2009. For the application of glyphosate at three doses, a plot with nine bushes was selected. The physicochemical properties of soil were analyzed prior to spraying of the chemical on the field. The soil of experimental field had a silty clay loam in texture $(26.2 \%$ sand, $41.1 \%$ silt and $29.8 \%$ clay) with an acidic $\mathrm{pH} 5.21^{18)}$ and $2.44 \%$ organic carbon ${ }^{19)}$ The fertility status of experimental field was medium in relation to the available nitrogen $(407.6 \mathrm{~kg} / \mathrm{ha})^{20)}$ and was higher in available phosphorus $(54.41 \mathrm{~kg} / \mathrm{ha})^{21)}$ and available potassium $(353 \mathrm{~kg} / \mathrm{ha}){ }^{18)}$

\section{Climatic conditions}

The temperature of the experimental area varied between mean minimum $11.1^{\circ} \mathrm{C}$ and mean maximum of $27.2^{\circ} \mathrm{C}$ in 2008 and 2009 (July-October). Total rainfalls of $1262.9 \mathrm{~mm}$ were recorded in 2008 and 2009. The average relative humidity ranged from $68-88 \%$ and $47-91 \%$ in 2008 and 2009, respectively.

\section{Application of the herbicide}

The glyphosate commercial formulation, Glycel (EC) containing $41 \%$ active ingredient was obtained from a local dealer in Palampur, India. In July of both years, Glycel was sprayed at 0.5 , 1.0 and $2.0 \mathrm{~kg} / \mathrm{ha} \mathrm{kg}$ equivalents to glyphosate/ha along with the control (no herbicide, water only) in both years by using a sprayed volume of $400 \mathrm{~L}$ water/ha with the help of a knapsack sprayer with a flat fan nozzle.

\section{Sample collection}

Periodic analysis of soil and tea samples was carried out at 0 (2 hr), 15, 30, 45, 60, 75 and 90 days after herbicide application. On each sampling day, soil and tea samples from all plots were collected and brought to the laboratory in plastic bags. Soil samples from all treatments were air-dried and passed through a

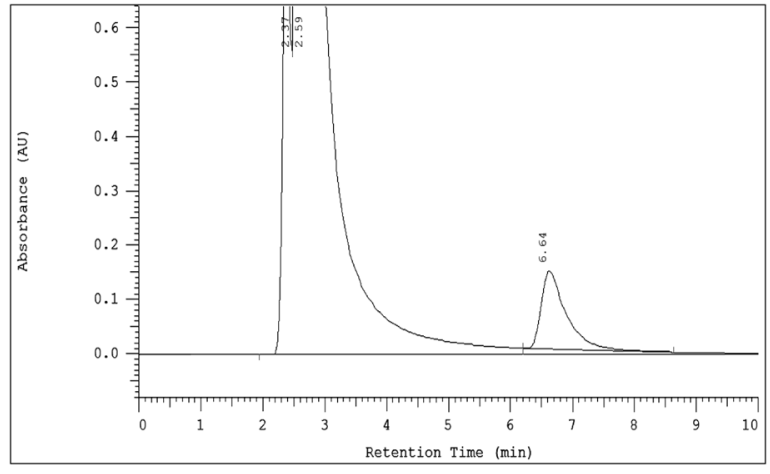

Fig. 1. HPLC profile of glyphosate.

2-mm sieve using CODEX Alimentarius standard protocols of residue analysis. ${ }^{22}$ ) Tea shoots (each containing two leaves and a bud) were collected, oven dried $\left(45^{\circ} \mathrm{C}\right)$, crushed to fine powder and then used for residue analysis.

\section{Glyphosate analyses}

Glyphosate (99.99\% purity) reference material was procured from AccuStandard, USA. The stock solution of glyphosate was prepared by dissolving $10 \mathrm{mg}$ of standard glyphosate in $10 \mathrm{~mL}$ of sodium tetraborate buffer ( $1 \mathrm{M}, \mathrm{pH} 9.0)$. Working standards $(2 \mathrm{~mL})$ of different concentrations prepared from the stock solution were taken in separate vials and $1.0 \mathrm{~mL}$ of sodium tetraborate was added to each vial followed by the addition of $1.0 \mathrm{~mL}$ of 9-fluoroenylmethyl chloroformate $(0.002 \mathrm{M}$ in acetone). These solutions were incubated for $30 \mathrm{~min}$ at room temperature for complete derivatization and were analyzed by modifying the method given by Simenson et al. ${ }^{23)}$

\section{Analysis of glyphosate residue}

The representative samples ( $50 \mathrm{~g}$ soil or $50 \mathrm{~g}$ tea) each in triplicate were taken for the analysis. Extraction in flasks was done with distilled water $(200 \mathrm{~mL})$. Flasks were shaken for $3 \mathrm{hr}$ in a reciprocating shaker. The content was filtered through Whatman filter paper No. 1 using activated charcoal. Extraction was repeated with $100 \mathrm{~mL}$ of distilled water; the combined filtrate was dried on hot plate at $30^{\circ} \mathrm{C}$ and $2 \mathrm{~mL}$ of sodium tetraborate $(1 \mathrm{M}$, $\mathrm{pH}$ 9.0) was added to it and derivatized as described above.

The residues of glyphosate in the derivatized extracts were quantified using a Merck-Hitachi HPLC equipped with a photodiode array detector (PDA) and a Zorbax $\mathrm{NH}_{2}(25 \mathrm{~cm} \times 4.6 \mathrm{~mm}$, $5 \mu \mathrm{m})$ column. Estimation was done at $206 \mathrm{~nm}$ using mobile phase $0.05 \mathrm{M}$ aq. $\mathrm{KH}_{2} \mathrm{PO}_{4}$ : acetonitrile $(50: 50)$ buffered at $\mathrm{pH}$ 6.0 with $7 \mathrm{~N} \mathrm{KOH}$ at $0.8 \mathrm{~mL} / \mathrm{min}$ flow rate using an injection volume of $20 \mu \mathrm{L}$. Under these conditions the retention time of glyphosate was found to be approximately $6.64 \mathrm{~min}$ (Fig. 1).

\section{Recovery experiment}

To estimate the efficiency of the method, a recovery experiment was conducted by fortifying untreated samples of soil with 0.01 , 0.10 and $0.50 \mu \mathrm{g} / \mathrm{g}$ glyphosate and tea leaves with $0.01,0.50$ and 
Table 1. Method validation by recovery analysis of glyphosate from test samples

\begin{tabular}{ccccc}
\hline Substrates & Amount fortified $(\mu \mathrm{g} / \mathrm{g})$ & Amount recovered $(\mu \mathrm{g} / \mathrm{g})$ & Recovery $(\%)$ & Average recovery $(\%)$ \\
\hline Soil & 0.01 & 0.007 & 70.0 & 72.0 \\
& 0.10 & 0.072 & 76.0 & 72.66 \\
\multirow{2}{*}{ Tea } & 0.50 & 0.380 & 61.0 & 74.0 \\
& 0.01 & 0.006 & 81.0 & 72.00 \\
\hline
\end{tabular}

$1.0 \mu \mathrm{g} / \mathrm{g}$ glyphosate (analytical standard $99.99 \%$ purity). ${ }^{24)}$ The fortified samples were extracted, derivatized and analyzed as per the methods described earlier.

\section{Results and Discussion}

\section{Recovery studies}

Fortification of the soil with glyphosate $(0.01,0.10$ and $0.50 \mu \mathrm{g} / \mathrm{g}$ ) showed that recoveries ranged from $70-76 \%$. Fortification of tea leaves with glyphosate $(0.01,0.50$ and $1.0 \mu \mathrm{g} / \mathrm{g})$ showed that recoveries ranged from $61-81 \%$ (Table 1 ).

\section{Glyphosate residues in the soil}

Initial deposits of glyphosate residues in the soil immediately after the application of glyphosate during the experiment in 2008 and 2009 were found to be 0.041 and $0.046 \mu \mathrm{g} / \mathrm{g}, 0.059$ and $0.061 \mu \mathrm{g} / \mathrm{g}$, and 0.075 and $0.080 \mu \mathrm{g} / \mathrm{g}$ at $0.5,1.0$ and $2.0 \mathrm{~kg} / \mathrm{ha}$ application rates, respectively. After 15 days glyphosate residues were found to be $0.007,0.021$ and $0.044 \mu \mathrm{g} / \mathrm{g}$ in 2008 at $0.5,1.0$ and $2.0 \mathrm{~kg} / \mathrm{ha}$ rates of application to tea plants. However glyphosate residues were found to be $0.010,0.026$ and $0.048 \mu \mathrm{g} / \mathrm{g}$, respectively in 2009 at the three doses of glyphosate application. Thus, the corresponding percentages of dissipation of the applied glyphosate in 2008 and 2009 were 82.98 and $73.07 \%, 64.00$ and $57.37 \%$, and 41.33 and $40.0 \%$, respectively 15 days after herbicide application.

Thirty days after the herbicide application, the dissipation of glyphosate was highest in the glyphosate with a $0.5 \mathrm{~kg} / \mathrm{ha}$ rate of application (97.56\% in Season I and $92.30 \%$ in Season II), followed by glyphosate application at $1.0 \mathrm{~kg} / \mathrm{ha}(86.88 \%$ in Season I and $86.88 \%$ in Season II). The least dissipation was found with the highest dose of glyphosate application i.e., $2.0 \mathrm{~kg} / \mathrm{ha}(68.00 \%$ in Season I and 66.25\% in Season II). This demonstrated that at higher doses glyphosate persisted in the soil for longer periods than at lower doses. Similar observations have been reported by several researchers. ${ }^{25,26)}$

The period of 30 days after herbicide application included total rainfalls of 636.4 and $626.5 \mathrm{~mm}$ during first and second year, respectively. The similar environmental conditions such as heavy rainfall, high average humidity $(>86 \%$ and $92 \%)$ and conducive temperatures during the 30 days after spraying with the herbicide, might have resulted in an almost complete rapid disappearance of the herbicide from the field. ${ }^{27,28)}$ In the field, losses due to adsorption or volatilization were also possible. The combined effect on herbicide dissipation by physico-chemical
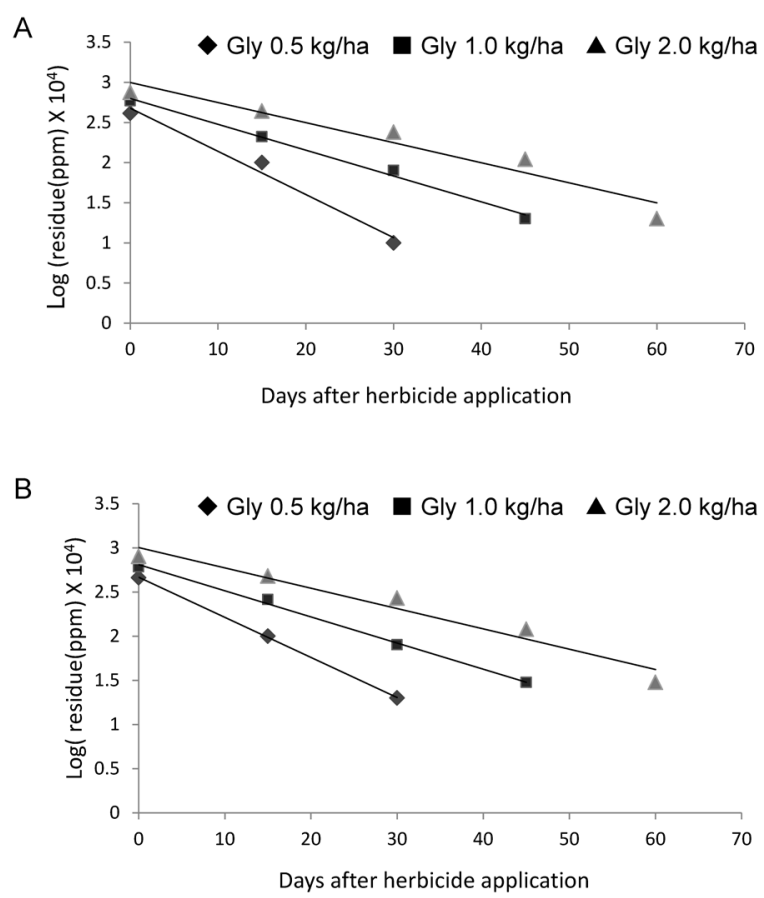

Fig. 2. First order degradation behaviour of glyphosate in soil 2008 (A) and 2009 (B).

parameters and environmental conditions, such as volatilization, vapor pressure, high organic matter, heavy texture of the soil, soil moisture content, high rainfall, and favorable temperatures has also been reported. ${ }^{28,29)}$

During both years of study, residues were found to be below detectable limits 45 days after glyphosate application at $0.5 \mathrm{~kg} /$ ha indicated that applied glyphosate persisted for up to 30 days in the soil. The concentration of glyphosate at $1.0 \mathrm{~kg} / \mathrm{ha}, 45$ days after herbicide application was found to be 0.002 and $0.003 \mu \mathrm{g} / \mathrm{g}$ and at $2.0 \mathrm{~kg} / \mathrm{ha}$ was 0.011 and $0.012 \mu \mathrm{g} / \mathrm{g}$ during Season I and Season II respectively. This showed the corresponding dissipation for glyphosate at $1.0 \mathrm{~kg} / \mathrm{ha}$ application was 96.61 and $95.08 \%$ and 85.33 and $85.00 \%$, respectively in 2008 and 2009 at 45 days. This also indicated that $14.67 \%$ glyphosate remained in the soil in Season I and $15.00 \%$ in Season II at a $2.0 \mathrm{~kg} / \mathrm{ha}$ application rate. However approximately 3.39 and 5.92\% glyphosate remained in the soil in Season I and II, respectively at a $1.0 \mathrm{~kg} / \mathrm{ha}$ application rate. 
Table 2. Dissipation of glyphosate in soil

\begin{tabular}{|c|c|c|c|c|c|c|}
\hline \multirow{3}{*}{$\begin{array}{l}\text { Sampling } \\
\text { intervals } \\
\text { (In days) }\end{array}$} & \multicolumn{6}{|c|}{ Residues $(\mu \mathrm{g} / \mathrm{g})$ and $\mathrm{M}^{*} \pm \mathrm{SD}(\%$ Dissipation) } \\
\hline & \multicolumn{2}{|c|}{$\mathrm{T}_{1}(0.5 \mathrm{~kg} / \mathrm{ha})$} & \multicolumn{2}{|c|}{$\mathrm{T}_{2}(1.0 \mathrm{~kg} / \mathrm{ha})$} & \multicolumn{2}{|c|}{$\mathrm{T}_{3}(2.0 \mathrm{~kg} / \mathrm{ha})$} \\
\hline & Season I & Season II & Season I & Season II & Season I & Season II \\
\hline 0 & $0.041 \pm 0.001(0.0)$ & $0.046 \pm 0.002(0.0)$ & $0.059 \pm 0.001(0.0)$ & $0.061 \pm 0.001(0.0)$ & $0.075 \pm 0.001(0.0)$ & $0.080 \pm 0.002(0.0)$ \\
\hline 15 & $0.007 \pm 0.001(82.98)$ & $0.010 \pm 0.001(73.07)$ & $0.021 \pm 0.002(64.40)$ & $0.026 \pm 0.003(57.37)$ & $0.044 \pm 0.002(41.33)$ & $0.048 \pm 0.001(40.00)$ \\
\hline 30 & $0.001 \pm 0.0001(97.56)$ & $0.002 \pm 0.001(92.30)$ & $0.008 \pm 0.002(86.88)$ & $0.008 \pm 0.001(86.88)$ & $0.024 \pm 0.001(68.00)$ & $0.027 \pm 0.002(66.25)$ \\
\hline 45 & BDL (100) & $\mathrm{BDL}(100)$ & $0.002 \pm 0.0001(96.61)$ & $0.003 \pm 0.001(95.08)$ & $0.011 \pm 0.001$ & $0.012 \pm 0.001(85.00)$ \\
\hline 60 & $\mathrm{BDL}$ & BDL & $\mathrm{BDL}$ & $\mathrm{BDL}$ & $0.002 \pm 0.0001(97.30)$ & $0.003 \pm 0.001(96.25)$ \\
\hline 75 & $\mathrm{BDL}$ & BDL & $\mathrm{BDL}$ & $\mathrm{BDL}$ & $\mathrm{BDL}$ & $\mathrm{BDL}$ \\
\hline 90 & BDL & BDL & $\mathrm{BDL}$ & BDL & $\mathrm{BDL}$ & BDL \\
\hline
\end{tabular}

$\mathrm{BDL}=$ Below detectable limit $(<0.001 \mu \mathrm{g} / \mathrm{g}) ; \mathrm{M}^{*}=$ Mean of five replicates.

Table 3. Regression equation, correlation coefficient and half life for dissipation of glyphosate in soil during different years

\begin{tabular}{ccccccc}
\hline Seasons & Treatments & Slope of curve (b) & Rate constant (k) & Regression equation & $\begin{array}{c}\text { Correlation } \\
\text { coefficient }\end{array}$ & Half-life (days) \\
\hline Season I (2008) & $0.5 \mathrm{~kg} / \mathrm{ha}$ & 0.001 & 0.119 & $y=-0.001 x+0.036$ & 0.859 & 5.82 \\
& $1.0 \mathrm{~kg} / \mathrm{ha}$ & 0.001 & 0.069 & $y=-0.001 x+0.050$ & 0.861 & 10.04 \\
& $2.0 \mathrm{~kg} / \mathrm{ha}$ & 0.001 & 0.027 & $y=-0.01 x+0.070$ & 0.964 & 25.66 \\
Season II (2009) & $0.5 \mathrm{~kg} / \mathrm{ha}$ & 0.001 & 0.102 & $y=-0.001 x+0.041$ & 0.881 & 6.79 \\
& $1.0 \mathrm{~kg} / \mathrm{ha}$ & 0.001 & 0.063 & $y=-0.001 x+0.053$ & 0.890 & 11.00 \\
& $2.0 \mathrm{~kg} / \mathrm{ha}$ & 0.001 & 0.022 & $y=-0.001 x+0.075$ & 0.971 & 31.50 \\
\hline
\end{tabular}

Table 4. Dissipation of glyphosate in tea leaves

\begin{tabular}{|c|c|c|c|c|c|c|}
\hline \multirow{3}{*}{$\begin{array}{l}\text { Sampling } \\
\text { intervals } \\
\text { (In days) }\end{array}$} & \multicolumn{6}{|c|}{ Residues $(\mu \mathrm{g} / \mathrm{g})$ and $\mathrm{M}^{*} \pm \mathrm{SD}(\%$ Dissipation) } \\
\hline & \multicolumn{2}{|c|}{$\mathrm{T}_{1}(0.5 \mathrm{~kg} / \mathrm{ha})$} & \multicolumn{2}{|c|}{$\mathrm{T}_{2}(1.0 \mathrm{~kg} / \mathrm{ha})$} & \multicolumn{2}{|c|}{$\mathrm{T}_{3}(2.0 \mathrm{~kg} / \mathrm{ha})$} \\
\hline & Season I & Season II & Season I & Season II & Season I & Season II \\
\hline 0 & $0.004 \pm 0.001(0.0)$ & $0.006 \pm 0.002(0.0)$ & $0.010 \pm 0.001(0.0)$ & $0.012 \pm 0.002(0.0)$ & $0.014 \pm 0.002(0.0)$ & $0.017 \pm 0.002(0.0)$ \\
\hline 15 & BDL (100) & $0.001 \pm 0.0001(83.33)$ & $0.002 \pm 0.001(80.00)$ & $0.003 \pm 0.001(75.00)$ & $0.003 \pm 0.001(78.57)$ & $0.004 \pm 0.002(76.47)$ \\
\hline 30 & $\mathrm{BDL}$ & $\mathrm{BDL}$ & $\mathrm{BDL}$ & $\mathrm{BDL}$ & $\mathrm{BDL}$ & $\mathrm{BDL}$ \\
\hline 45 & $\mathrm{BDL}$ & $\mathrm{BDL}$ & $\mathrm{BDL}$ & $\mathrm{BDL}$ & $\mathrm{BDL}$ & $\mathrm{BDL}$ \\
\hline 60 & $\mathrm{BDL}$ & BDL & $\mathrm{BDL}$ & $\mathrm{BDL}$ & $\mathrm{BDL}$ & $\mathrm{BDL}$ \\
\hline 75 & BDL & BDL & $\mathrm{BDL}$ & BDL & BDL & $\mathrm{BDL}$ \\
\hline 90 & BDL & $\mathrm{BDL}$ & BDL & $\mathrm{BDL}$ & $\mathrm{BDL}$ & $\mathrm{BDL}$ \\
\hline
\end{tabular}

$\mathrm{BDL}=$ Below detectable limit $(<0.001 \mu \mathrm{g} / \mathrm{g}) ; \mathrm{M}^{*}=$ Mean of three replicates.

\section{Dissipation kinetics of glyphosate in soil}

The logarithmic plots of herbicides residues versus time have been presented in Fig. 2. The plots indicate that the dissipation of glyphosate at all the three levels of application viz. 0.5, 1.0 and $2.0 \mathrm{~kg} / \mathrm{ha}$ fit for the first order kinetics decay curve during both years. The slopes of the curve, coefficients, and the rate constants along with the regression equations are summarized in Table 3. The correlation coefficients $(r)$ for the three applied doses in 2008 and 2009 were found to be 0.86 and 0.88 ; 0.86 and 0.89 ; and 0.96 and 0.97 , respectively indicating a perfect fit. In the first and second season of the experiment, half-life values for the glyphosate in the soil were found to be 5.80 and 6.79 days; 10.05 and 11.07 days; and 16.34 and 19.10 days, respectively (Table 3 ). Nomura and Hilton ${ }^{25)}$ reported the half life of glyphosate to be 19.2 days. However, according to the Weed Science Society of America, glyphosate has moderate field persistence with a typical field half-life of 44-66 days, which is quite significantly higher than the present findings. ${ }^{30,31)}$ The lower values of halflife values in the present investigation of the soil may be due to the combined effect of high organic carbon, high rainfall and moderate temperatures.

\section{Glyphosate residue in tea leaves}

The concentration of glyphosate and its dissipation in tea leaves as a result of three levels of glyphosate application at $0.5,1.0$ and $2.0 \mathrm{~kg} / \mathrm{ha}$ is presented in Table 4 . The initial deposits of glyphosate residue in tea leaves immediately after glyphosate application at $0.5,1.0$ and $2.0 \mathrm{~kg} / \mathrm{ha}$ were found to be 0.004 , 
0.010 , and $0.014 \mu \mathrm{g} / \mathrm{g}$ respectively in 2008 and $0.006,0.012$ and $0.017 \mu \mathrm{g} / \mathrm{g}$, respectively in 2009 . Fifteen days after herbicide application, glyphosate residues were found to be below the detection limit (BDL) in lower dose and with the 1.0 and $2.0 \mathrm{~kg} /$ ha doses, residues were $0.001 \mu \mathrm{g} / \mathrm{g}$ and $0.002 \mu \mathrm{g} / \mathrm{g}$, respectively in 2008. Glyphosate residues were found to be $0.003,0.003$ and $0.004 \mu \mathrm{g} / \mathrm{g}$, respectively in 2009 at $0.5,1.0$ and $2.0 \mathrm{~kg} / \mathrm{ha}$ application rates. Thirty days after herbicide application, residues were below detectable levels in all glyphosate treatments indicate the complete degradation/disappearance of glyphosate in tea leaves. Prematilake et al. ${ }^{17)}$ demonstrated that when glyphosate is used in excess of $0.5 \%(>2.7 \mathrm{~kg} / \mathrm{ha})$ on tea lands glyphosate residues have been detected until 14 days after application, whereas glyphosate residues have not been detected in tea seven days after application when the rates are below $0.5 \%$. Beltman et al. ${ }^{32)}$ observed in one of four repetitions of an experiment that under wet conditions of the brick-soil system, infiltration decreased and therefore the runoff of water and glyphosate increased.

From the data regarding glyphosate residue in tea plants and its corresponding dissipation in the soil, it was found that the rate of the disappearance of glyphosate in plants was rapid during the initial periods which could be due to metabolization by the plants via oxidative cleavage of the carbon-nitrogen $(\mathrm{C}-\mathrm{N})$ bond to yield aminomethyl phosphoric acid (AMPA) and the breaking of carbon-phosphorus (C-P) by carbon phosphorus lyase to produce sarcosine. ${ }^{33,34)}$ Glyphosate is highly soluble in water $(11,600 \mathrm{mg} / \mathrm{L})$ and has a very low octanol-water partition coefficient $\left(\log K_{\mathrm{ow}}=-3.2\right.$ to -2.8$)$. However, Edwards et al. $\left.{ }^{30}\right)$ demonstrated that, in some field experiments, approximately $2 \%$ of the applied glyphosate dissipated from the soil due to run-off. In one case, a loss of $1.85 \%$ of the applied glyphosate was observed in a field treated at twice the recommended application rate, with more than $99 \%$ of the total runoff occurring during a severe rainstorm the day after application. Wash off by rainfall appeared to be the major route of dissipation. ${ }^{28,30)}$

The glyphosate concentrations in the tea leaves were found to be below the maximum residue limit $(1 \mathrm{mg} / \mathrm{kg})$. Presently no residue limit for glyphosate is set by the CODEX Alimentarius. However a maximum residue limit (MRL) is set at $0.2 \mathrm{mg} / \mathrm{kg}$ by the CODEX Alimentarius organization for another herbicide that is frequently used in tea gardens in India. The Environmental Protection Agency (EPA), has set the MRL in dry tea leaves at $1 \mathrm{mg} / \mathrm{kg}$, however the European Union has set it at $0.01 \mathrm{mg} / \mathrm{kg}$.

\section{Conclusion}

Glyphosate persisted in the soil for 30 to 60 days, following applications of 0.5 to $2.0 \mathrm{~kg} / \mathrm{ha}$ in tea crops. Glyphosate residues in the tea leaves were detected up to 15 days at all three treatment doses. The above findings indicate that glyphosate dissipated in tea plants within 15 days of application and that it is safe to use glyphosate in tea plantations at a recommended dose of $1.0 \mathrm{~kg} /$ $\mathrm{ka}$ in tea gardens. However, on the basis of the present study the mechanism of the degradation behavior of glyphosate could not be confirmed and needs further investigation.

\section{References}

1) B. W. Bolling, C.-Y. O. Chen and J. B. Blumberg: Curr. Opin. Clin. Nutr. Metab. Care 12, 42-48 (2009).

2) Z. Yang, Y. Xu, G. Jie, P. He and Y. Tu: Asia Pac. J. Clin. Nutr. 16(S1), 148-152 (2007).

3) Tea Board of India: http://teaboard.gov.in/pdf/statgrowers (Accessed 27 Mar., 2015).

4) D. J. Rajkhowa, I. C. Barua, R. P. Bhuyan and N. T. Yaduraju: "Weed Management in Tea," Tech. Bull. NRC for Weed Science, 2005.

5) H. Panda: "The Complete Book on Cultivation and Manufacture of Tea" Asia Pacific Business Press Inc., pp. 284-285, 2011.

6) V. S. Rao, F. Rahman, S. N. Sharma and H. S. Singh: Proc. 28th Tocklai Conference. pp. 61-63 (1971).

7) S. Sondhia, P. Singh and V. Parmar: Ind. J. Agric. Sci. 84, 579-584 (2014).

8) F. Rahman: Two and a Bud 38, 28-30 (1991).

9) S. Sondhia: Environ. Monit. Assess. 162, 163-168 (2010).

10) S. Sondhia and A. Dixit: ORYZA, Int. J. Rice 49, 178-182 (2012).

11) S. Sondhia: Bull. Environ. Contam. Toxicol. 89, 1032-1036 (2012).

12) S. Sondhia: Pestic. Res. J. 19, 119-121 (2007).

13) M. L. Rueppel, B. B. Brightwell, J. Schaefer and J. T. Marvel: J. Agric. Food Chem. 25, 517-528 (1977).

14) M. E. Damanakis: Annu. Inst. Phytopathol. Benaki 1, 153-167 (1976).

15) S. A. E. Kools, M. van Roovert, C. A. M. van Gestel and N. M. van Straalen: Soil Biol. Biochem. 37, 1303-1307 (2005).

16) A. J. Cessna and J. Waddington: Can. J. Plant Sci. 75, 759-762 (1995).

17) K. Prematilake: "Be Cautious in Using Glyphosate for Weed Control in Uea," Daily News http://archives.dailynews.lk/2004/06/24/fea05. html (Accessed on 23 May, 2014).

18) M. L. Jackson: "Soil Chemical Analysis," Prentice Hall of India Private Ltd., New Delhi, 1967.

19) C. S. Piper: "Soil and Plant Analysis," Hans Publishers Co. Bombay, pp. 59-63, 1966.

20) B. V. Subbiah and G. L. Asija: Curr. Sci. 25, 259-266 (1956).

21) S. R. Olsen, C. V. Cole and F. S. Watanabe: USDA Circ. 939 (1954).

22) Codex Alimentarius Commission: CAC/GL 33-1999.

23) L. Simonsen, I. S. Fomsgaard, B. Svesmark and N. H. Spliid: J. Environ. Sci. Health 43B, 365-375 (2008).

24) S. Sondhia: Environ. Monit. Assess. 137, 205-211 (2008).

25) N. S. Nomura and H. W. Hilton: Weed Res. 17, 113-121 (1977).

26) D. N. Roy, S. K. Konar, S. Banerjee, D. A. Charles, D. G. Thompson and R. Prasad: J. Agric. Food Chem. 37, 437-440 (1989).

27) J. H. Montgomery: "Agrochemicals Desk Reference: Environmental Data," Lewis Publishers, Chelsea MI, p. 626, 1993.

28) S. Sondhia: Environ. Monit. Assess. 147, 463-469 (2008).

29) P. Kudsk: Proc. BCPC Conf. Weeds 2001, Brighton UK, pp. 405-504 (2001).

30) W. M. Edwards, G. B. Triplett and R. M. Kramer: J. Environ. Qual. 9, 661-665 (1980).

31) Weed Science Society of America (ed.): "Glyphosate Herbicide Handbook," 6th Ed. Weed Science Society of America, Champaign, Illinois, pp. 146-149, 1989.

32) W. H. J. Beltman, H. J. J. Wieggers, M. L. de Rooy and A. M. Matser: Alterra-rapport 319, Wageningen (2001).

33) R. E. Hoagland: Weed Sci. 28, 393-400 (1980).

34) K. N. Reddy, A. M. Rimando and S. O. Duke: J. Agric. Food Chem. 52, 5139-5143 (2004). 